飲酒によりめまい，眼振が謤発された 1 症例

\author{
加地美千子・中島 務

\section{Vertigo Attacks after Drinking Alcohol; Report of a Case Recorded by Electronystagmography}

\author{
Michiko Kachi and Tsutomu Nakashima \\ (Nagoya University)
}

\begin{abstract}
It is well known that nystagmus appears even in normal people after drinking alcohol, and this is called positional alcohol nystagmus (PAN). However, there have been few reports in which actual nystagmus was recorded after drinking alcohol in patients with inner ear diseases. Here we report a patient who developed vertigo after drinking, which was recorded on an electronystagmogram during the alcohol loading test.
\end{abstract}

Key words : vertigo, drinking, alcohol, nystagmus

はじめに

正常な人においてもアルコール摂取後に頭位性眼振が 起きることがあり, positional alcohol nystagmus (PAN) 1) 5) として報告されている. また，メニエール病患者はアル コール摂取後はめまい発作を誘発しやすくなるのでアル コール摂取を控えるようにいわれることが多い。しかし 実際，メニエール病患者あるいは内耳疾患患者において アルコール摂取後の眼振が記録された報告はほとんどな い. 今回われわれは，アルコールを 2 度摂取させて 2 度 ともめまい，眼振が誘発され，それを記録することがで きたアルコールとの関連が明らかな症例を経験したので 報告する。

症例 : 58 歳, 男性.

\section{症例}

主訴：回転性めまい，左耳鳴.

既往歷：特記すべきことなし。

現病歷とめまいの経過: 1984 年, 風邪をひいた数日後, ゴルフ中にめまい発作が起きた. 1985 年, 1986 年と 1 年 に $3 \sim 4$ 回ビール 1 缶 $(350 \mathrm{ml})$ ほどの飲酒後, $3 \sim 4$ 時
間持続する回転性めまい発作が起きるようになった。 1987 年頃より 1 年に 7 〜 回ほどの頻度でめまいが起き るようになったが, そのうち約半数は飲酒後, 約半数が 飲酒とは関係なく起こった。当院初診は 1995 年 11 月. めまいはいつも周辺の景色が時計回りにまわると訴え た. めまい発作時左耳鳴が大きくなる傾向がある. めま い発作総数とそのうちの飲酒後のめまい発作回数の年度 別推移は図 1 のごとくである.

検查所見 :

MRI：頭蓋内に異常はなく聴神経腫瘍も認められな かった.

IgE・RAST 法：小麦，麦芽，いずれも陰性.

標準純音聴力検査 : 左側高音域に軽度の感音難聴があ る (図 2). 1995 年 11 月の初診から 2001 年 3 月まで経時 的に聴力検查を行っているが，明らかな聴力の変動はな い.

カロリックテスト：眼振の大きさは左耳に入れた時は 右耳に比べ小さかったが眼振の持続時間に左右差は認め られなかった。

vestibular evoked myogenic potential（VEMP）：右側に 

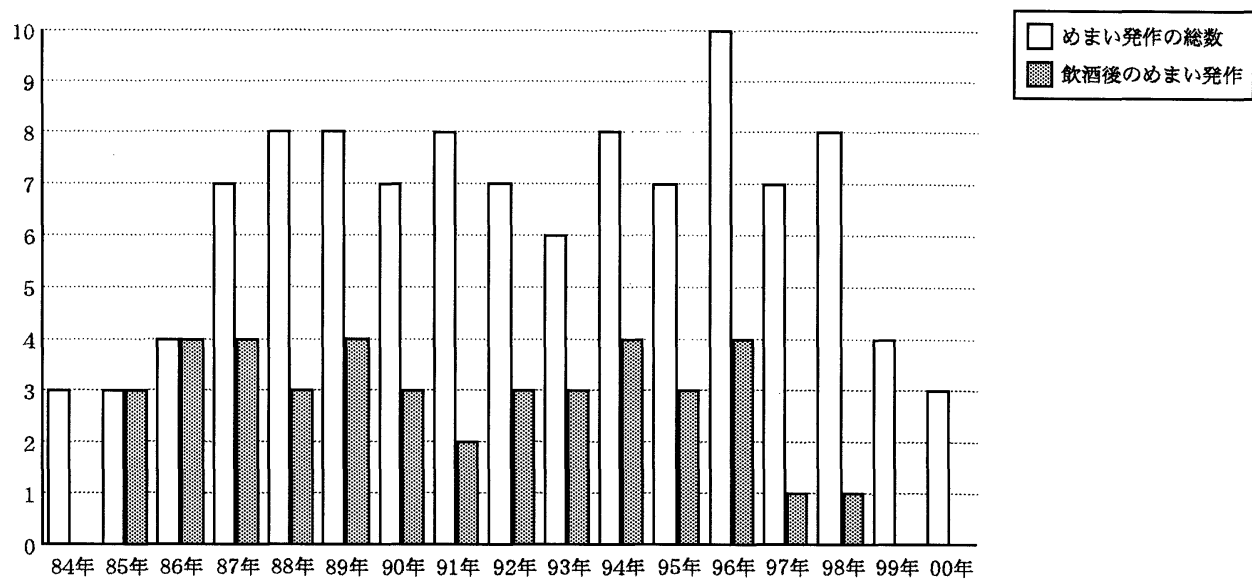

図 1 めまい発作回数の年度別推移
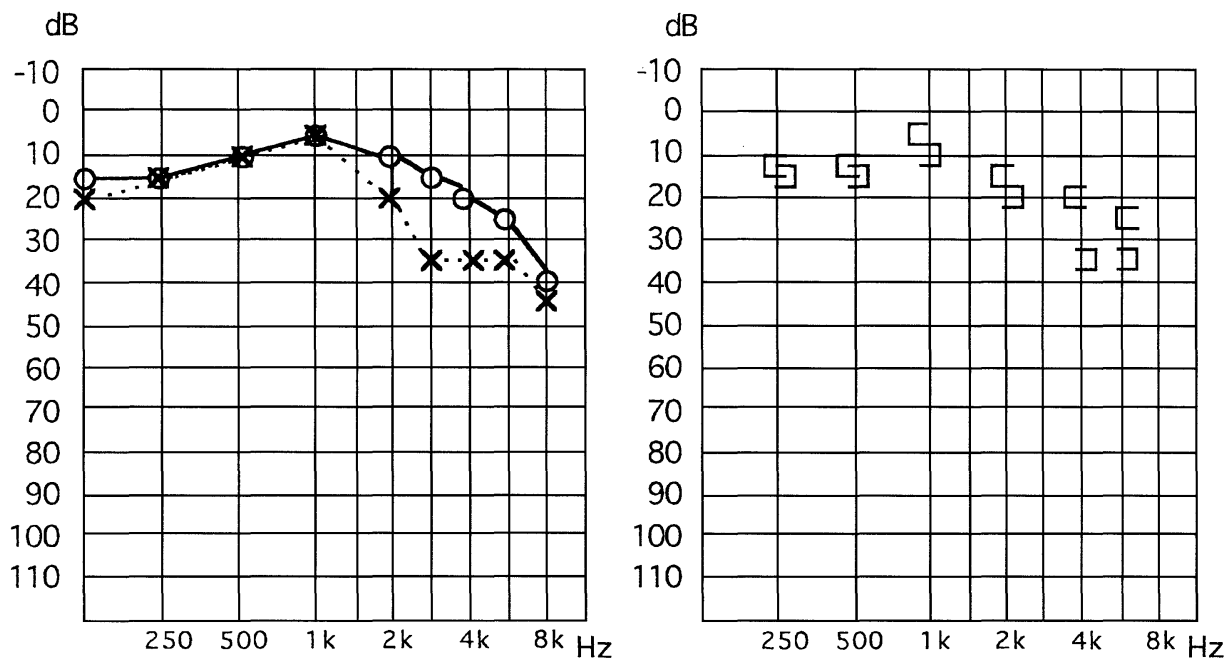

図 2 標準純音聴力検査（1997 年 10 月 9 日）

反応を認めたが左側ではっきりしなかった.

耳音響放射： distortion product otoacoustic emission （DPOAE）は図 3 のように全体的に反応が抑制されてい るが左耳では特に高音域の反応が悪い. transient evoked otoacustic emission (TEOAE) の wave reproducibirity は右 耳で $86 \%$, 左耳で $79 \%$ と両耳とも再現性があった。

\section{アルコール負荷検査}

実際に飲酒によりめまい発作があらわれるかどうか調 べた. 患者には飲酒後に眼振を伴うめまいが起きるかど らかを調べるために協力をお願いし同意を得た，あらか じめ自発眼振, 頭位眼振, 注視眼振を認めないことを確
認し，外来でビールとワインの飲酒による負荷試験を行 いENG を測定した。

ビール負荷：1996 年 11 月 28 日

ビール $400 \mathrm{ml}$ （アルコール $22 \mathrm{ml}$ ）を患者に飲んでむ らったところ， 25 分後右向き眼振が生じた．頭位変換に ても眼振は変化なかった。安静臥位の ENG は図 4 のご とくである. 最大緩徐相速度 $15^{\circ} /$ 秒であった. 最大緩徐 相速度は図 5 のように飲酒後 1 時間をピークに次第に低 下していく傾向にあった。 またこのビール負荷により耳 鳴や聴力の変化は認めなかった。 約 3 時間後も眼振はま だ残っていたが歩行可能であったので州宅となった。䚻 宅後も $5 \sim 6$ 時間はめまい感は残っていたという. 


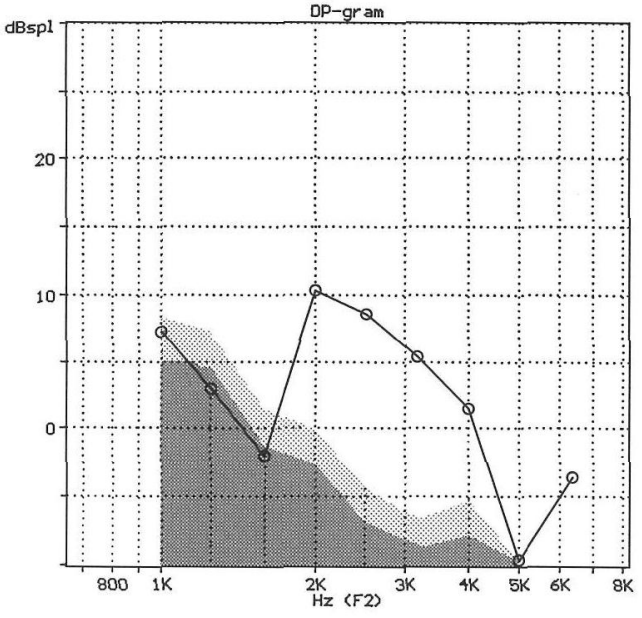

(a)

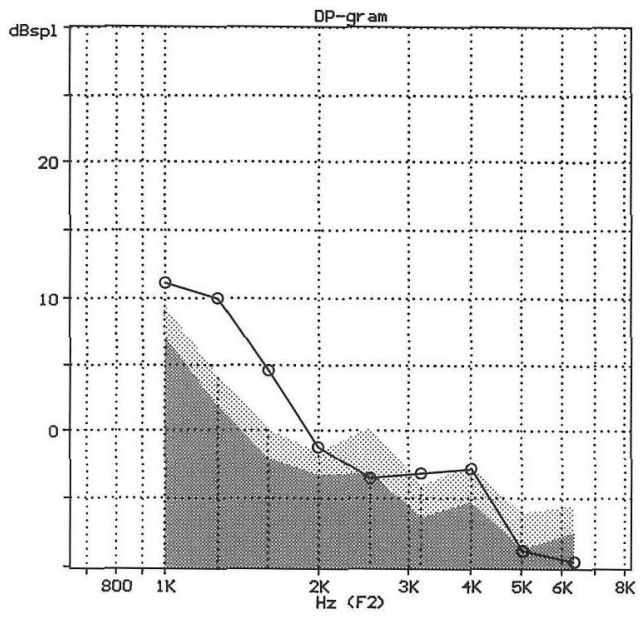

(b)

図 3 DPOAE

(a) 右耳, (b) 左耳

ワイン負荷：1997 年 1 月 16 日

ワイン $280 \mathrm{ml}$ （アルコール $36 \mathrm{ml}$ ）を患者に飲んでも らったところ 50 分後に右向き眼振が生じた。ビール負荷 時と同様に頭位変化はなく耳鳴や聴力変化むなかった。 自覚するめまいの程度はビール負荷時と同等であった。 約 3 時間眼振を観察し帰宅させた。ビール負荷時と同様 に帰宅後も 5 〜 時閒めまい感残っていたといらこと である。

その後の経過：アルコール負荷試験後からはアルコー ルを控えているが，30 分から 1 時間でおさまる程度の軽 いめまいが年 7 ～ 8 回起きていた. 1999 年からは完全に 禁酒したところ，めまい発作回数は減少し発作の程度も 軽くはなったが，それでもまだめまい発作は年に $3 \sim 4$ 回出現している。 なお 1997 年 6 月，メニエール病のめま い発作ではなく良性発作性頭位性眩量（BPPV）様のめ まいが出現したが Epley 法にて軽快している。

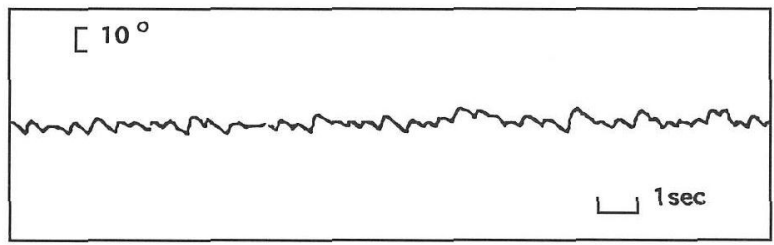

図 4 ビール負荷後の ENG
考察

本症例は回転性めまい発作を繰り返し，外来でのアル コール負荷時は耳鳴の増強を訴えなか力っだ，ほとんど の例でめまい発作時には左耳鳴が大きくなると訴えた。 中枢性神経疾患が否定できたことから厚生省研究班 （1974）作成のメニエール病診断の手引きより，メニエー ル病の確実例と考えた。感音難聴がある左耳に VEMP が はっきり出なかったことは病変が左耳にあるとして矛盾 がない。

飲酒後の眼振については過去にもいくつかの報告1) 5)

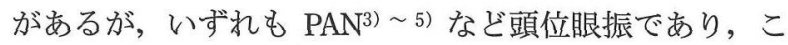
れに対し今回の症例ではめまい発作が起こり右向きの眼

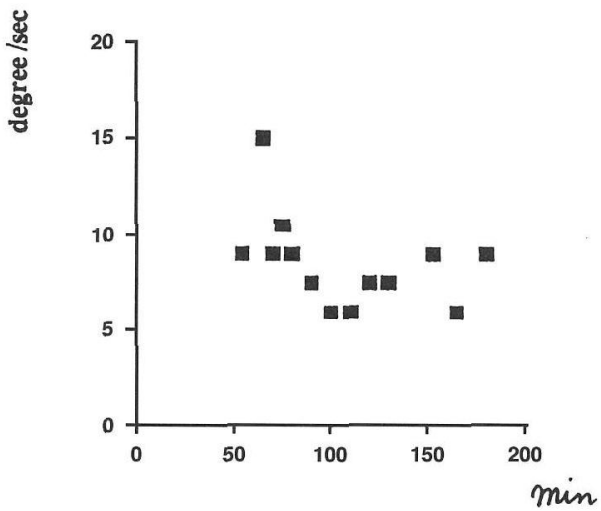

図 5 ビール負荷後の眼振の最大緩徐相速度 


\section{振が誘発された。}

左内耳に病変があることから左側で血液内耳関門の異 常が起きている可能性がある．アルコールを摂取すると 内耳液中にアルコールが移行しやすくなり相対的にクプ ラと内耳液の比重に差が生じやすい状態となり，めまい 発作を引き起したと推察できる. PANでむ内耳液へのア ルコールの移行が報告されており, 内耳液の比重の変化 が眼振と密接に関連していると考えられる.

また, もともと左耳に病変があり飲酒により大脳皮質 の抑制がとれ4)6) 神経系が内耳一何らかの影響を及ぼし, めまい発作を誘発した可能性も存在する．いずれにして も本症例はアルコールが内耳に直接的あるいは間接的に 影響を及ぼし内耳性眼振が誘発されたものと考えられ る. なお小麦が原因と思われるメニエール病症例の報告7) もあるが本症例ではビールだけでなくワインでもめまい 発作が誘発されていることやRAST 法の結果により食餌 性アレルギーは否定できる.

\section{まとめ}

1. 飲酒後の回転性めまい発作を訴える貴重な症例を経 験した。

2. この症例に対しビール負荷, ワイン負荷を行い, と もに負荷後めまい発作を生じた，右向き眼振を認め眼振
記録を行った。

3. 諸々の検查結果により病態について考察した.

\section{参考文献}

1) Wilkinson IMS, Kime $R$ and Purnell $M$ : Alcohol and human eye movement. Brain $97: 785 \sim 792,1974$.

2) Schroeder DJ : Some effects of alcohol on nystagmus and vertigo during caloric and optokinetic stimulation. Ann Otol Rhinol Laryngol $81: 218 \sim 229,1972$.

3) Aschan G : Differennt types of alchohol nystagmus. Acta Otolaryngolol Suppl $140: 69 \sim 78,1958$.

4) Umeda $Y$ and Sakata E : Alcohol and the oculomotor system. Ann Otol Rhinol Laryngol $87: 392 \sim 398,1978$.

5) Money $\mathrm{KE}$ and Myles WS : Heavy water nystagmus and effects of alcohol. Nature $247: 404 \sim 405,1974$.

6）高須俊明 : 急性アルコール中毒一その神経学的側面一. 神 経内科 $10: 236 \sim 245,1979$.

7）朴沢二郎：小麦が原因と思われるメニエール病症例. Equilibrium Res $34: 106 \sim 107,1975$.

原稿受付：平成13年 1 月 17 日

原稿採択 : 平成13年 5 月 30 日

別刷請求先：加地美千子

干 466-8550 名古屋市昭和区鶴舞町 65

名古屋大学医学部耳鼻咽喉科学教室 